\title{
Sequestering Divalent Nickel Ions from Aqueous Solution Using Activated Carbon of Citrus limetta Peel: Isothermic and Kinetic Studies
}

\author{
Lakshmanaperumal Vidhya $^{1 *}$, Munusamy Dhandapani ${ }^{1}$, Kuppusamy Shanthi ${ }^{2}$ \\ ${ }^{1}$ Department of Chemistry, Sri Ramakrishna Mission Vidhyalaya College of Arts and Science, \\ Coimbatore-641020, Tamil Nadu, India \\ ${ }^{2}$ Department of Environmental Sciences, PSG College of Arts and Science, \\ Coimbatore-641014, Tamil Nadu, India
}

Received: 25 January 2017

Accepted: 21 February 2017

\begin{abstract}
The biochar (activated carbon) derived from Citrus limetta peel waste biomaterial, was tested for the removal of nickel (II) ions from aqueous solution. Batch experiments were conducted with nickel concentration, $\mathrm{pH}$, and dosage to estimate the nickel ions sequestration from aqueous solution. Among the models employed, Langmuir Isotherm fit well with the adsorption data. The kinetic data analysed with Lagergren and Ho Models fit well with pseudo first-order. Maximum removal (99.8\%) of Ni(II) was observed at $\mathrm{pH} 7$, with $0.05 \mathrm{~g}$ adsorbent dosage of $\mathrm{Ni}(\mathrm{II})$ solution $100 \mathrm{mg} \mathrm{L}^{-1}$. The characterization of biochar carried out by using a scanning electron microscope (SEM), energy-dispersive x-ray spectrometer (EDX), and Fourier transform infrared spectrometer (FT-IR) revealed interaction with Ni(II) ions and the formation of isolated aggregates on the biosorbent surface. The results indicate that Citrus limetta peel biochar can effectively be used for the removal of nickel ions from aqueous solution.
\end{abstract}

Keywords: Nickel (II) ion adsorption, Citrus limetta peel biochar, isotherm and kinetic models, SEM and EDAX, FT-IR

\section{Introduction}

Heavy metal ions like copper, nickel, zinc, cadmium, lead, chromium, and mercury have been documented as pollutants in the environment [1]. Nickel, a toxic heavy metal, is introduced into natural water systems mainly from many chemical industries viz., textile dyeing,

*e-mail: vidhuram236@gmail.com electroplating, and metal finishing. Nickel is reported to cause severe environmental hazards and public health issues. Even after carefully measuring discharged nickel(II) ions into the ecosystem, we still see serious threats of allergies, cardiovascular issues, gastrointestinal irritation, kidney disease, and lung fibrosis to [2]. The permissible discharge level of $\mathrm{Ni}$ (II) from industrial effluent into water bodies is $3 \mathrm{mg} \mathrm{L}^{-1}$ and in drinking water for human consumption is less than $40 \mu \mathrm{g} \mathrm{L} \mathrm{L}^{-1}$. The main source of freshwater contamination can be attributed 
to the release of untreated sanitary and toxic industrial effluent and overflow from agricultural fields [3]. Thus it is necessary to remove the nickel before disposal of industrial waste. Although some known methods such as chemical precipitation, electro-coagulation, ion exchange, surface adsorption, and membrane filtration are already being used to remove heavy metals, these methods are cumbersome and costly [4]. In recent years, agricultural wastes have been extensively studied for their use in the removal of metal from water. These wastes comprise peat, wood, bark, husk, dust, peel, and leaves [5-7]. With this view, Citrus limetta peel, a plentiful waste material, was made into biochar (activated carbon) and then used here to study its adsorption ability of $\mathrm{Ni}(\mathrm{II})$ ions from aqueous solution. Thus, the purpose of the present study was to: (i) incorporate and characterize biochar from Citrus limetta peel, (ii) assess the potential of Citrus limetta peel biochar for the removal of $\mathrm{Ni}$ (II) from aqueous solution, (iii) evaluate the influence of experimental variables on $\mathrm{Ni}$ (II) adsorption onto Citrus limetta peel biochar, and (iv) analyze adsorption kinetics and isotherms to understand the mechanism of $\mathrm{Ni}(\mathrm{II})$ removal.

\section{Materials and Methods}

\section{Biochar Preparation}

The Citrus limetta peel was collected from various fruit shops in Coimbatore and was sun-dried before being kept in hot air oven at $100^{\circ} \mathrm{C}$ for $24 \mathrm{~h}$. The dehydrated material was compressed and fed into a pyrolysis stove (Safire Scientific Company) at Tamil Nadu Agricultural University, Coimbatore. The charred (biochar) activated carbon sample was collected, and their significant characteristics were analyzed before conducting experiments.

\section{Characterization of Citrus limetta Peel Biochar}

The biochar sample of Citrus limetta peel was sieved $(<0.25 \mathrm{~mm})$ and their water-holding capacity, zeta potential, and particle size were analyzed by standard methods [8]. Furthermore, proximate analyses of the Citrus limetta peel biochar were also carried out.

\section{Zeta Potential Study}

A nanoparticle analyzer (Horiba Scientific Nanopartica, Japan) was used to carry out the zeta potential (on the surface charge) of the Citrus limetta biochar. About $0.5 \mathrm{~g}$ of Citrus limetta peel biochar was suspended in $20 \mathrm{~mL}$ of solution with $\mathrm{pH}$ of $4,5.5,7,8$, and 9 was allowed to settle for about 30 minutes [9]. The samples were then tested three times, with five readings for each run. The output data were obtained in the form of mobility, zeta potential, and conductance.

\section{Fourier Transform Infrared Spectroscopic Analysis}

The adsorption capacity of Citrus limetta peel biochar depends not only on porosity but also on chemical reactivity of functional groups at the surface of the adsorbent. The chemical reactivity creates an imbalance between forces at the exterior and inside the body of the adsorbent, thus resulting in Van der Waals force to create a molecular adsorption [10].

\section{Scanning Electron Microscopy and EDAX Analysis}

Electron microscopy studies yield the interaction and non-interaction of logarithmic phase cells. Small pinches of Citrus limetta peel biochar powder were fixed on a $10 \mathrm{~mm}$ metal stub using carbon tape [10]. The samples were sputter-coated with gold under vacuum in an argon atmosphere and analyzed at $20 \mathrm{kV}$ for the tungsten filament. The surface topography of the coated sample and the elemental analyses of non-interacted log phase biochar and $\mathrm{Ni}$ (II) interacted log phase biochar were carried out by Energy Dispersive X-ray spectroscopy (EDAX) using Quanta FEI 250 (Czechoslovakia) equipment.

\section{Adsorption Experiments}

A stock solution of $\mathrm{Ni}$ (II) $\left(1,000 \mathrm{mg} \mathrm{L}^{-1}\right)$ was prepared by dissolving NiSO4.6H2O (E Merck) (procured from Himedia Laboratories India (Molecular weight 294.18, 99.9\% Assay)) in deionized water. Desired concentrations of Nickel (II) solutions were prepared by diluting the stock solution. The $\mathrm{pH}$ of the solution was adjusted using $0.1 \mathrm{~N} \mathrm{HCl}$ or $0.1 \mathrm{~N} \mathrm{NaOH}$ solutions [11]. Other test concentrations between 50 and $250 \mathrm{mg} \mathrm{L}^{-1}$ at an increment of $50 \mathrm{mg} \mathrm{L}^{-1}$ were prepared from the stock solution.

Nickel concentration was determined by UVspectrophotometer (Systronics visis, Canada; model No. 167) using the dimethy glyoxime method. The adsorption of nickel (II) ion was determined by taking $0.05 \mathrm{~g}$ of Citrus limetta peel biochar in $250 \mathrm{ml}$ Erlenmeyer flasks with $25 \mathrm{ml}$ of initial concentrations (50-250 $\left.\mathrm{mg} \mathrm{L}^{-1}\right)$ of nickel solution and were further agitated using a mechanical shaker (Orbit Shaker, Taiwan) at $150 \mathrm{rpm}$. After proper mixing, the resultant solution was allowed to equilibrate for a period of $120 \mathrm{~min}$. The samples were filtered prior to analysis in order to minimize interference of the carbon fines. The wavelength of operation was kept at $470 \mathrm{~nm}$. By standard calibration graph, the absorbance of the supernatant solution was measured to determine the residual $\mathrm{Ni}(\mathrm{II})$ concentration. All the investigations were carried out in triplicate and the mean values were reported to avoid any inconsistency in experimental results. The metal solution controls (check) were kept throughout the experiment. The adsorption capacity at equilibrium $\mathrm{q}_{e}$ was determined [12]. The percentage removal of divalent nickel was calculated for each run as follows. 


$$
\text { Removal capacity }(\%)=\frac{\mathrm{Co}-\mathrm{Ce}}{\mathrm{Co}} * 100
$$

...where $\mathrm{C}_{\mathrm{o}}$ and $\mathrm{C}_{\mathrm{e}}$ represent the initial and equilibrium concentrations of nickel ion in aqueous solution. The adsorption capacity for each concentration of nickel (II) at equilibrium was determined by the following expression [13].

$$
\text { Adsorption capacity }=q_{e} \frac{(m g)}{(g)}=\frac{C_{o}-C_{e}}{m} * V
$$

...where $\mathrm{V}$ is the volume of solution in litres and $\mathrm{m}$ is the mass of the adsorbent used in grams.

\section{Optimization Studies of Ni(II) Adsorption}

The batch adsorption studies with different parameters were analyzed by using known concentrations, dosages, and $\mathrm{pH}$. Concentrations ranging from $50-250 \mathrm{mg} \mathrm{L}^{-1}$ with $\mathrm{pH}$ from 3 to 8 and activated carbon dose of 0.01-0.05 g were used for optimization. Experiments were carried out for 120 minutes taking absorbance measurement in every 10-min interval. To fix the optimum concentration of $\mathrm{Ni}(\mathrm{II})$ ions, the $\mathrm{pH}$ and adsorbent dosage were kept at 7 and $0.05 \mathrm{~g}$, respectively. Similarly, optimum dosage was determined by keeping $\mathrm{pH} 7$ and concentration at $100 \mathrm{mg} \mathrm{L}^{-1}$. The optimum $\mathrm{pH}$ was determined by maintaining $0.05 \mathrm{~g}$ of the adsorbent and $100 \mathrm{mg} \mathrm{L}^{-1}$ of nickel ion concentration. In every trial, after adsorption the sorbate was decanted and separated from the sorbent by centrifuge and the supernatant liquid was analyzed for the residual metal concentration and the residual carbon was used for further studies.

\section{Adsorption Isotherm Models}

Adsorption isotherm explains the adsorbate interaction with adsorbents and therefore is significant in optimizing the use of adsorbents and it is necessary to create the most fitting correlation for the equilibrium curve [14]. Among several options, very important isotherm models (viz., Langmuir, Freundlich, and Temkin mathematical calculations) were selected to study the mode of interaction of $\mathrm{Ni}(\mathrm{II})$ ions with biochar at equilibrium. Langmuir, (Eq. 3), Freundlich, (Eq. 4), and Temkin (Eq. 5) isotherms were plotted by using standard straight-line equations and corresponding two parameters $\mathrm{C}_{e}$ and $\mathrm{q}_{\mathrm{e}}$ for nickel ion.

$$
\begin{gathered}
\frac{\mathrm{C}_{\mathrm{e}}}{\mathrm{q}_{\mathrm{e}}}=\frac{\mathrm{C}_{\mathrm{e}}}{\mathrm{Q}_{\max }}+\frac{1}{\mathrm{~K}_{\mathrm{ad}} * \mathrm{Q}_{\max }} \\
\log q_{e}=\left\lfloor\log K_{f}+\left\langle\frac{1}{n}\right\rangle \log \mathrm{C}_{\mathrm{e}}\right\rfloor
\end{gathered}
$$

...where $\mathrm{q}_{\mathrm{e}}$ (mg g-1) is the amount of metal adsorbed and $\mathrm{C}_{\mathrm{e}}\left(\mathrm{mg} \mathrm{L}^{-1}\right)$ is concentration at equilibrium. Qmax (mg g $\left.\mathrm{g}^{-1}\right), \mathrm{b}\left(\mathrm{L} \mathrm{mg}^{-1}\right)$ and $\mathrm{Kad}\left(\mathrm{L} \mathrm{mg}^{-1}\right)$ are Langmuir isotherm parameters [15-16].
$\mathrm{K}_{\mathrm{f}}$ and $\mathrm{n}$ are Freundlich isotherm parameters ${ }^{3}$. Ce ( $\mathrm{mg} \mathrm{L}^{-1}$ ) is the concentration of $\mathrm{Ni}$ (II) ions at equilibrium, qe $\left(\mathrm{mg} \mathrm{g}^{-1}\right)$ is the equilibrium adsorption capacity and $\mathrm{n}$ is the heterogeneity factor. $\mathrm{K}_{\mathrm{f}}$ and $\mathrm{n}$ can be determined from a linear plot of $\log \mathrm{q}_{\mathrm{e}}$ against $\log \mathrm{C}_{\mathrm{e}}$ [17-18].

The Temkin isotherm equation correlates the equilibrium metal concentration with the heat of adsorption due to adsorbent-adsorbate interactions.

$$
\mathrm{qe}=\mathrm{B} \ln \mathrm{A}+\mathrm{B} \ln \mathrm{Ce}
$$

...where $\mathrm{B}=\mathrm{RT} / \mathrm{b}, \mathrm{b}$ is the Temkin constant related to heat of adsorption $\left(\mathrm{J} \mathrm{mol}^{-1}\right)$, $\mathrm{A}$ is the Temkin isotherm constant $\left(\mathrm{L} \mathrm{g}^{-1}\right), \mathrm{R}$ is the gas constant $\left(8.314 \mathrm{~J} \mathrm{~mol}^{-1} \mathrm{~K}^{-1}\right)$, and $\mathrm{T}$ is the absolute temperature (K) [19].

\section{Adsorption Kinetics}

The adsorption kinetics of $\mathrm{Ni}(\mathrm{II})$ on Citrus limetta biochar was studied for its possible utilization in the treatment of industrial effluents. The first-order rate constant for adsorption of $\mathrm{Ni}(\mathrm{II})$ has been analyzed with the help of Lagergran's equation [20].

$$
\log \left(q_{e}-q_{t}\right)=\log q_{e}-\frac{k_{1} t}{2.303}
$$

...where $\mathrm{q}_{\mathrm{e}}$ is the amount of metal adsorbed at equilibrium $(\mathrm{mg} / \mathrm{g})$, and $\mathrm{q}$ is the amount of metal adsorbed at time $\mathrm{t}$ $(\mathrm{mg} / \mathrm{g})$.

$\mathrm{k} 1=$ rate constant of adsorption (per minute)

$\mathrm{t}=$ Time (minute)

Pseudo second-order rate equation [21]:

$$
\frac{\mathrm{t}}{\mathrm{q}_{\mathrm{t}}}=\frac{1}{\mathrm{k}_{2} \mathrm{q}_{\mathrm{e}}}+\frac{\mathrm{t}}{\mathrm{q}_{\mathrm{e}}}
$$

...where $\mathrm{k}_{2}$ is the second-order rate constant for adsorption $\left(\mathrm{g} \mathrm{mg}{ }^{-1} \mathrm{~min}^{-1}\right), \mathrm{q}_{\mathrm{e}}$ is the amount of metal adsorption at equilibrium ( $\mathrm{mg} \mathrm{g}^{-1}$ ), and $\mathrm{qt}$ is the amount of metal adsorption in time $\mathrm{t}\left(\mathrm{min}^{-1}\right)$. The graphs $\log \left(\mathrm{q}_{\mathrm{e}}-\mathrm{q}_{\mathrm{t}}\right)$ vs, $\mathrm{t}$ and $t / q_{t}$ vs. $t$ depict the metal sorption for first- and secondorder rate kinetic models, respectively [22].

\section{Results and Discussion}

\section{Characterization of Biochar}

The results on the proximate analyses of the Citrus limetta peel biochar sample are presented in Table 1 and the schematic representation of $\mathrm{Ni}(\mathrm{II})$ adsorption onto biochar in Fig. 1. The fixed carbon content of the sample was high, which indicates high carbonization. The $\mathrm{pH}$ was high, signifying the alkalinity of the biochar. The electrical conductivity of the biochar was 1.91 . Zeta potential is a measure of charge stability that controls all particleparticle interaction within a suspension, and in this study the zeta potential of biochar was found to be $-7.9 \mathrm{mV}$. 
Table 1. Characteristics of Citrus limetta peel biochar.

\begin{tabular}{|c|c|}
\hline Characteristics & Value \\
\hline $\mathrm{pH}$ & 10.0 \\
\hline EC & $1.91\left(\mathrm{ds} \mathrm{m}^{-1}\right)$ \\
\hline Water-holding capacity & $224.31(\%)$ \\
\hline Moisture content & $2.08(\%)$ \\
\hline Volatile content & $14(\%)$ \\
\hline Fixed carbon content & $70(\%)$ \\
\hline Ash content & $16(\%)$ \\
\hline Zeta potential & $-7.9(\mathrm{mV})$ \\
\hline Particle size & 1.00 \\
SP Area ratio & $380.9(\mathrm{~nm})$ \\
Mean & $56.0(\mathrm{~nm})$ \\
Standard deviation & $376.7(\mathrm{~nm})$ \\
\hline Mode &
\end{tabular}

The characteristics of the Citrus limetta biochar had been discussed in detail in our previous study [9].

The stability behaviour of Citrus limetta biochar was found to be incipient unstable. The $\mathrm{pH}$ value is high, which may be due to the detachment of alkali metals such as $\mathrm{Ca}$ and $\mathrm{Mg}$ from the biochar. A similar conclusion was noted with the biochar generated from sugar cane bagasse [23]. The increase in adsorption capacity with increase in $\mathrm{Ni}(\mathrm{II})$ concentration may be due to the higher adsorption rate and consumption of all energetic sites available for adsorption at higher concentration or due to higher accessibility of $\mathrm{Ni}(\mathrm{II})$ ions in the solution for the adsorption [24]. This is mainly due to the greater availability of surface area and adsorption sites, which in turn brings about greater removal of Ni ions [25]. The increase in percentage of

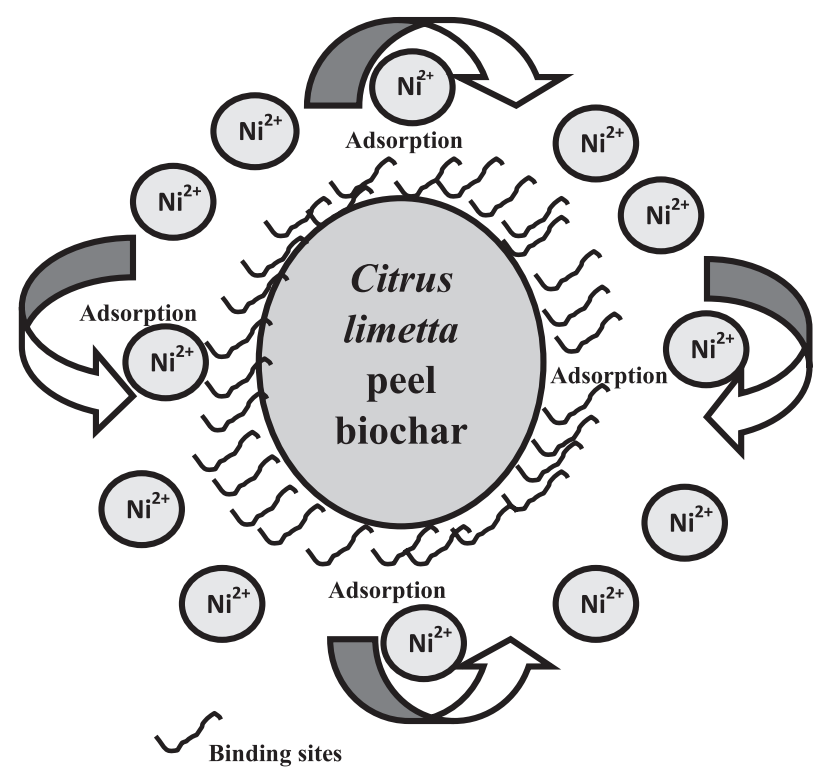

Fig. 1. Schematic representation of $\mathrm{Ni}$ (II) adsorption onto Citrus limetta peel biochar.

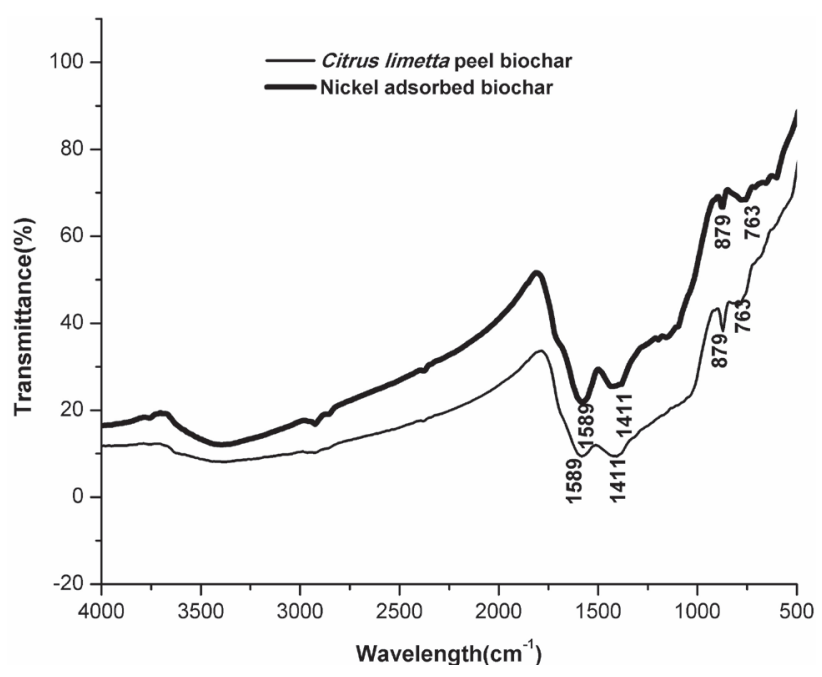

Fig. 2. FT-IR spectra of Citrus limetta peel biochar before and after $\mathrm{Ni}$ (II) adsorption.

metal ion removal with the increase in $\mathrm{pH}$ can be explained on the basis of a decrease in competition between proton and $\mathrm{Ni}$ (II) ions for the same functional group, and by a decrease in positive surface charge, which results in a lower electrostatic repulsion between surface and metal ions. A decrease in adsorption at higher $\mathrm{pH}$ is due to the formation of soluble hydroxyl complexes [26]. More than $80 \%$ removal of $\mathrm{Ni}$ (II) by Brassera oleracea at $\mathrm{pH}$ 5 was also reported [7]. Increasing $\mathrm{pH}$ from 5 resulted in reductions in adsorption. But the present study contradicts the earlier works and demonstrates that $\mathrm{pH} 7$ as the best suitable condition for Citrus limetta peel biochar.

\section{FT-IR, SEM, and EDAX Analyses}

It is evident from the FT-IR, SEM, and EDAX studies that the adsorption of $\mathrm{Ni}$ (II) on to Citrus limetta peel biochar with due reasons. The FT-IR spectrum of nickelloaded Citrus limetta peel biochar showed a noticeable difference from the FT-IR spectrum of Citrus limetta peel biochar. The FT-IR spectra of Citrus limetta peel biochar before and after adsorption of nickel were used to establish the vibration frequency of the functional groups in the adsorbents. In general, the biochar is a residual complex of organic compounds containing groups such as carboxylic acid, hydroxyl, ketones, aromatic moieties, and unsaturated compounds. Both the spectra of Citrus limetta peel biochar were measured in the range between 4,000 and $400 \mathrm{~cm}^{-1}$. The spectra were plotted using the same scale on the transmittance axis for the adsorbent before and after adsorption (Fig. 2). The results suggest that FT-IR spectrum of Citrus limetta biochar (before adsorption) had a broad band at $1,589 \mathrm{~cm}^{-1}$ associated with the $\mathrm{CO}_{2}^{-}$stretching vibration, and the peak at $879 \mathrm{~cm}^{-1}$ may be due to $\mathrm{C}-\mathrm{H}$ bending of the alkyl group. The band at $1,411 \mathrm{~cm}^{-1}$ is attributed to aromatic C-C stretching vibration. The frequency at $779 \mathrm{~cm}^{-1}$ before adsorption shifted to $763 \mathrm{~cm}^{-1}$ after adsorption. This is due to the 
formation of a weak bond between $\mathrm{Ni}$ and the ketonic group of the biochar [27].

SEM analysis is useful in understanding the porous structure of the biochar. There are holes and openings which are permeable structures, and heterogeneous rough surface with crater-like pores in Citrus limetta peel biochar that definitely increase the surface area available for adsorption (Fig. 3). Asymmetrical shape and the surface exhibit a micro-rough texture, which can support the adherence of heavy metals on to biosorbents [28-29]. It is very clear from the image that the porous surface has adsorbed nickel ions, confirming the sequestering process. Moreover, the EDAX spectra of preferred region of biochar before and after adsorption were recorded to investigate the chemical constituents in the biochar sample, further confirming the adsorption of $\mathrm{Ni}$ (II) ions (Fig. 4). EDAX analysis also identifies the presence of potassium, calcium, and phosphorus in both control and test samples. In short, the Citrus limetta peel biochar both by physical and chemical means is capable of adsorbing the nickel up to $99 \%$ from aqueous solution.

a)

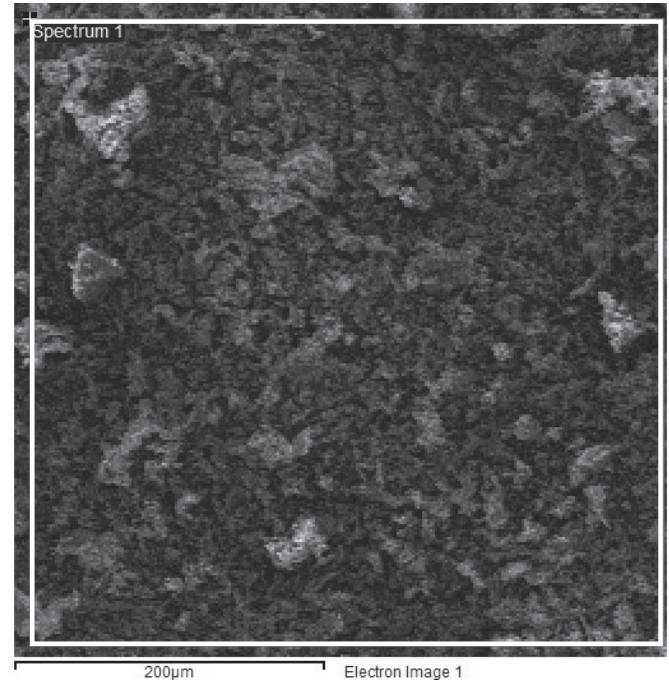

b)

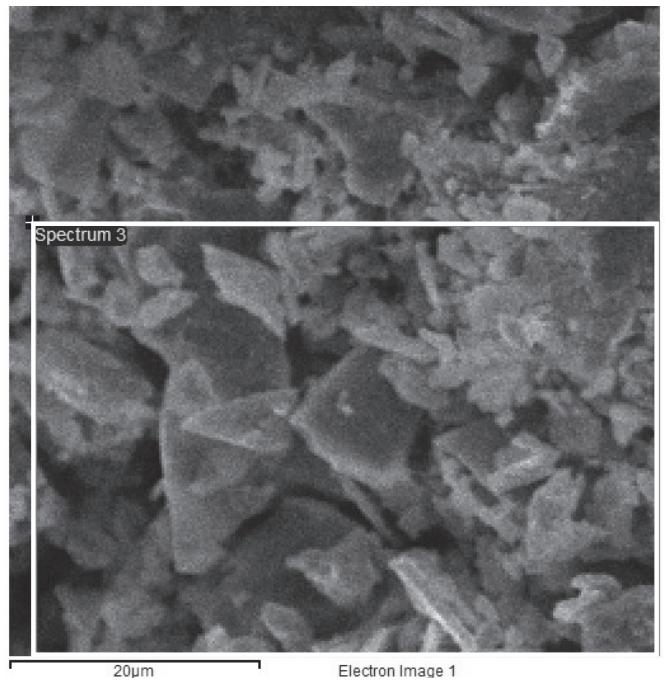

Fig. 3. SEM micrograph of Citrus limetta peel biochar before a) and after b) $\mathrm{Ni}(\mathrm{II})$ adsorption.

\section{Optimization of $\mathrm{Ni}(\mathrm{II})$ Adsorption}

The uptake of $\mathrm{Ni}(\mathrm{II})$ from aqueous solution by Citrus limetta biochar increased with time and attained equilibrium in $120 \mathrm{~min}$ for all the concentrations studied (Fig. 5a). The concentration of the solution varied from 50 to $250 \mathrm{mg} \mathrm{L}^{-1}$ with a dosage $0.05 \mathrm{~g}$ and at $\mathrm{pH} 7$ [30]. The equilibrium time was independent of initial Ni(II) concentration. When the concentration was $100 \mathrm{mg} \mathrm{L}^{-1}$, the percent removal of $\mathrm{Ni}(\mathrm{II})$ was $99.8 \%$ by the Citrus limetta biochar. Fig. 5b) represents the effect of the dosage of biochar on the removal of $\mathrm{Ni}(\mathrm{II})$. The dosage amount increased from 0.01 to $0.05 \mathrm{~g}$ and equilibrated for $120 \mathrm{~min}$ with the $\mathrm{Ni}$ (II) concentration of $100 \mathrm{mg} \mathrm{L}^{-1}$ and at $\mathrm{pH}$ 7. The percentage removal was 99.41 at $0.05 \mathrm{~g}$ dose. This study corroborates with previous adsorption studies of $\mathrm{Cr}(\mathrm{VI})$ onto biochar $[9,31]$. The most significant controlling parameter in the adsorption process is $\mathrm{pH}$. The level of removal of $\mathrm{Ni}$ (II) ions was investigated by changing the $\mathrm{pH}$ from 2 to 8, and the results are shown in Fig. 5c). It was noticed that with the increase in the $\mathrm{pH}$ of the solution, the amount of $\mathrm{Ni}$ (II) ion removal also increased. Maximum adsorption was observed at $\mathrm{pH} 7$ [32].

\section{Adsorption Isotherms}

An adsorption isotherm describes the stability relationship between the adsorbate concentration in the liquid phase and that on the adsorbents surface at a given

a)

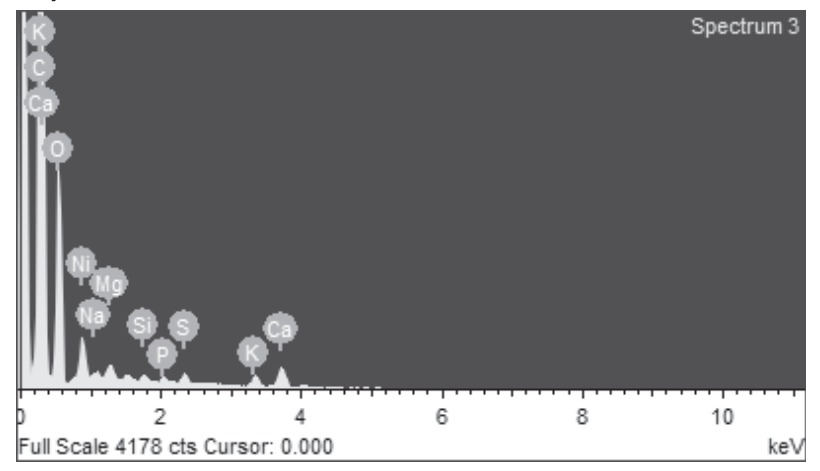

b)

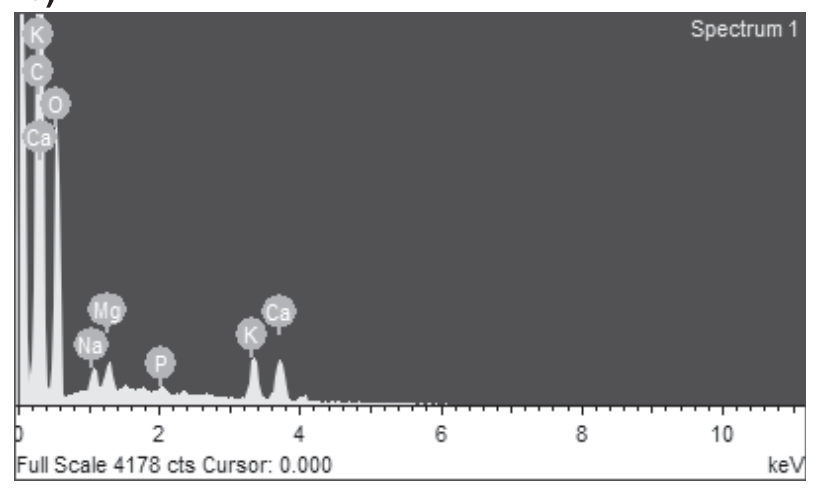

Fig. 4. Energy dispersive spectrum of Citrus limetta peel biochar before a) and after b) $\mathrm{Ni}(\mathrm{II})$ adsorption. 

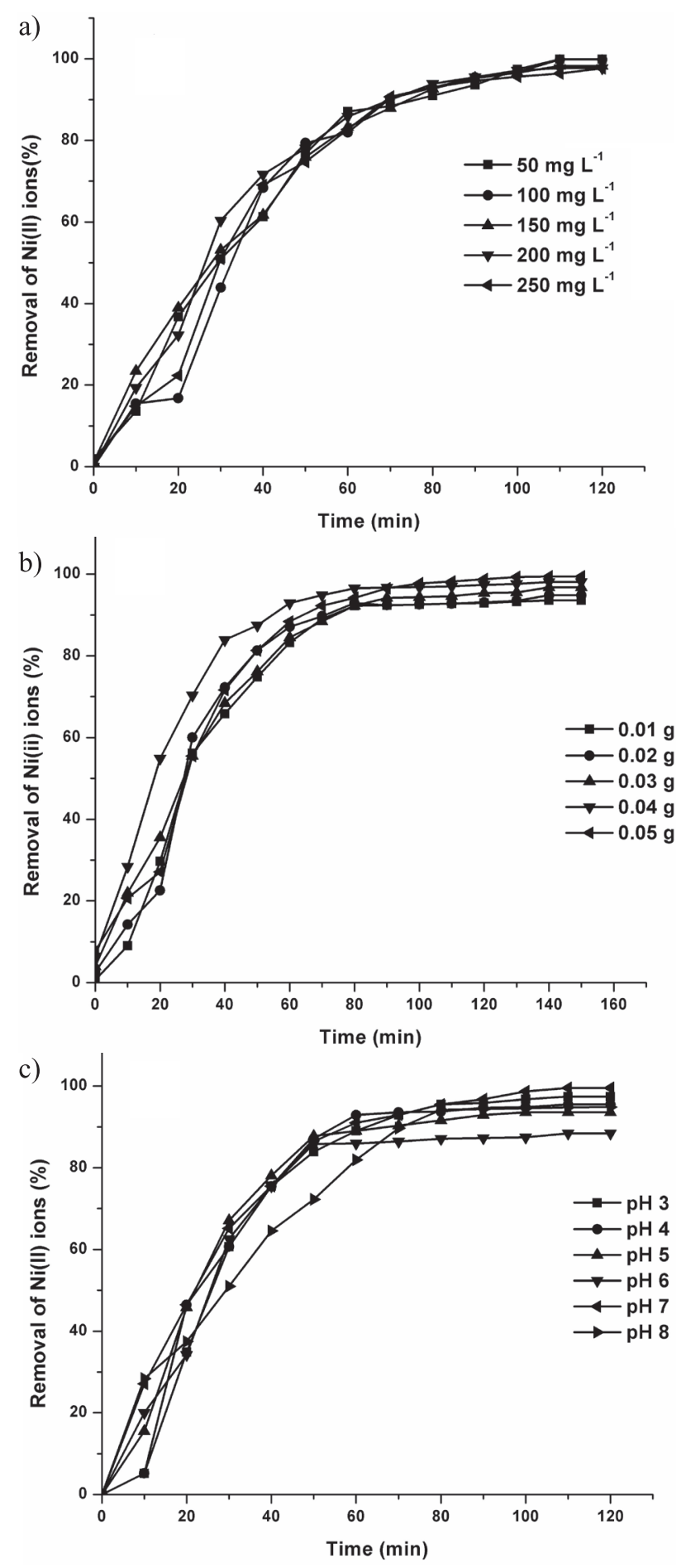

Fig. 5. Effect of concentration a), dosage b) and $\mathrm{pH}$ c) on the removal of Ni (II) by Citrus limetta peel biochar where, $\mathrm{a}=$ effect of concentration at $\mathrm{pH} \mathrm{7,} \mathrm{adsorbent} \mathrm{dose} 0.05 \mathrm{~g}$ and contact time 120 mins; $b=$ effect of Dosage at $\mathrm{pH} 7$, concentration $100 \mathrm{mg} \mathrm{L}-1$ and contact time 120 mins; and $\mathrm{c}=$ Effect of $\mathrm{pH}$ at concentration $100 \mathrm{mg} \mathrm{L}-1$, contact time 120 mins and dosage $0.05 \mathrm{~g}$.

condition. Among several options, Freundlich, Langmuir, and Temkin isotherm models were used here to describe the equilibrium relationship. The Langmuir isotherm model explains the sorption phenomena and suggests that uptake occurs on a homogeneous surface by monolayer

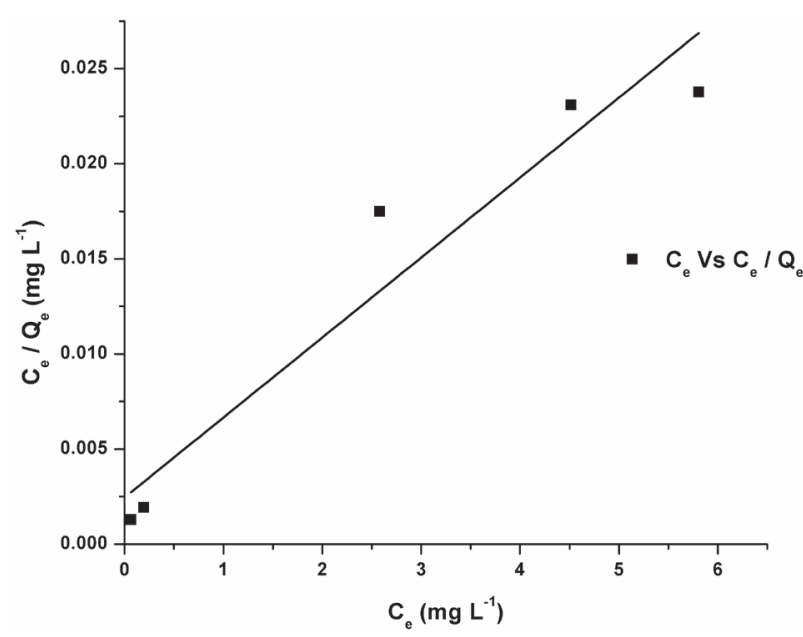

Fig. 6. Langmuir isotherm of $\mathrm{Ni}$ (II) adsorption by Citrus limetta peel biochar at $\mathrm{pH} 7$, dosage $0.05 \mathrm{~g}$ and contact time 120 mins.

sorption. The plots of specific sorption $\left(\mathrm{C}_{\mathrm{e}} / \mathrm{q}_{\mathrm{e}}\right)$ against the equilibrium concentration $\left(\mathrm{C}_{\mathrm{e}}\right)$ for nickel(II) are shown in Fig. 6 and the linear isotherm parameters, $Q_{e}$, b, and the coefficient of determinations are found in Table 2. We observed that the Langmuir adsorption isotherm was the befitting model for the sorption of nickel(II) from aqueous solution using Citrus limetta peel biochar, which has correlation coefficient $\left(\mathrm{R}^{2}\right)$ of 0.9312 , indicating favourable adsorption [7]. In the batch adsorption process the Langmuir Isotherm can be used to express whether a sorption system is favourable or not. The necessary features of the isotherm can be expressed in terms of separation factor (RL), which can be explained by the following relationship. The values of RL reflect the type of Langmuir isotherm. RL value can be calculated by the formula, $R L=1 /\left(1+b^{*} \mathrm{Co}\right)$. When the RL value is zero, the adsorption process is irreversible. When RL value is between 0 and 1 the process is favourable, and if it is greater than 1 the process is unfavourable (Table 2). The RL values in the present study are found to be between 0.002 and 0.01 , which indicate that the isotherm is a favourable one. The present study suggests that it has high $\mathrm{Q}_{\max }$ values. Mao et al. (2010) reported that the adsorbent with high $Q_{\max }$ values is usually advantageous for the wastewater treatment process [33]. High $\mathrm{Kf}$ values also indicate that the saturation time for adsorption of metal ions was attained quickly due to high affinity of activated bioadsorbent towards adsorbate, while low $\mathrm{Kf}$ values indicate low adsorption rate of metal ions [34].

In the Freundlich isotherm the magnitude of constant $1 / \mathrm{n}$ gives an indication of the favourability of adsorption. The value of $n>1$ represents favourable adsorption conditions (or) if the value of $1 / \mathrm{n}$ lies in the range of 1 to 10 , the adsorption is favourable. The values of $1 / \mathrm{n}$ were low for nickel ions in this study (Table 2), revealing that the $1 / \mathrm{n}$ and $\mathrm{Kf}$ values in Freundlich isotherm are not found to fit this adsorption data. The Temkin adsorption isotherm model was preferred to assess the adsorption potentials of the adsorbent for the adsorbates. The Temkin 
Table 2. Langmuir, Freundlich, and Temkin isotherm constants for nickel ion adsorption by Citrus limetta peel biochar.

\begin{tabular}{|c|c|c|c|c|c|c|c|c|c|}
\hline \multirow{2}{*}{$\begin{array}{c}\text { Citrus limetta peel } \\
\text { biochar }\end{array}$} & \multicolumn{3}{|c|}{ Langmuir isotherm } & \multicolumn{3}{|c|}{ Freundlich isotherm } & \multicolumn{3}{|c|}{ Temkin isotherm } \\
\hline & $\begin{array}{c}\mathrm{Q}_{\max } \\
\left(\mathrm{mg} \mathrm{g}^{1}\right)\end{array}$ & $\begin{array}{c}\mathrm{B} \\
\left(\mathrm{L} \mathrm{mg}^{-1}\right)\end{array}$ & $\mathrm{R}^{2}$ & $\begin{array}{c}\mathrm{K}_{\mathrm{f}} \\
\left(\mathrm{mg} \mathrm{g}^{-1}\right)\end{array}$ & $\begin{array}{c}\mathrm{n} \\
\left(\mathrm{L} \mathrm{mg}^{-1}\right)\end{array}$ & $\mathrm{R}^{2}$ & $\begin{array}{c}\mathrm{A} \\
\left(\mathrm{L} \mathrm{g}^{-1}\right)\end{array}$ & $\begin{array}{c}\mathrm{B} \\
\left(\mathrm{J} \mathrm{mol}^{-1}\right)\end{array}$ & $\mathrm{R}^{2}$ \\
\hline Concentration & 237.78 & 1.71447 & 0.9319 & 129.8307 & 0.32558 & 0.9310 & 35.627 & 41.9232 & 0.90542 \\
\hline $\mathrm{pH}$ & 86.988 & 7.59726 & 0.9968 & 98.83871 & 0.03 & 0.7743 & 24.634 & -0.0055 & 0.75540 \\
\hline Dosage & 87.700 & 3.84258 & 0.9983 & 96.59201 & 0.007 & 0.6221 & 14.082 & 0.06058 & 0.66364 \\
\hline
\end{tabular}

Table 3. Biosorption kinetics of Ni (II) on Citrus limetta peel biochar.

\begin{tabular}{|c|c|c|c|c|c|c|c|}
\hline \multirow{2}{*}{$\begin{array}{l}\text { Conc. } \\
\left(\mathrm{mg} \mathrm{L}^{-1}\right)\end{array}$} & \multirow{2}{*}{$\begin{array}{c}\mathrm{Qe} \\
\text { (Expt.) } \\
\mathrm{mg} \mathrm{g}^{-1}\end{array}$} & \multicolumn{3}{|c|}{ Pseudo first-order } & \multicolumn{3}{|c|}{ Pseudo second-order } \\
\hline & & $\begin{array}{l}\mathrm{q} \text { (Calc.) } \\
\mathrm{mg} \mathrm{g}^{-1}\end{array}$ & $\underset{\mathrm{K}_{1}}{\mathrm{~min}^{-1}}$ & $\mathrm{R}^{2}$ & $\begin{array}{l}\mathrm{q} \text { (Calc.) } \\
\mathrm{mg} \mathrm{g}^{-1}\end{array}$ & $\begin{array}{c}\mathrm{K}_{2} \\
\left(\mathrm{~g} \mathrm{mg}^{-1} \min ^{-1}\right)\end{array}$ & $\mathrm{R}^{2}$ \\
\hline 50 & 49.935 & 63.60231 & -0.03568 & 0.980008 & 71.7751 & 0.0002874 & 0.7877 \\
\hline 100 & 99.806 & 145.031 & -0.03844 & 0.923076 & 171.064 & 0.0000753 & 0.4536 \\
\hline 150 & 147.42 & 231.5246 & -0.04213 & 0.968226 & 187.158 & 0.0001638 & 0.9239 \\
\hline 200 & 195.48 & 310.7597 & -0.03989 & 0.954364 & 224.504 & 0.0001114 & 0.8730 \\
\hline 250 & 244.19 & 418.7852 & -0.04456 & 0.974525 & 377.026 & 0.0000461 & 0.6877 \\
\hline
\end{tabular}

Note: Conc.-Concentration, Expt.-Experimental, Calc.-Calculated; triplicate experiments were carried out and mean values were reported.

isotherm plot for the Ni(II) ions is presented in Table 2. It was observed that the Temkin adsorption isotherm also fits the adsorption data with the sorption of $\mathrm{Ni}$ (II) from aqueous solution using Citrus limetta peel biochar and has correlation coefficient $\left(\mathrm{R}^{2}\right)$ of 0.9054 . Comparative $\mathrm{R}^{2}$ values (correlation coefficients) of the Langmuir, Freundlich, and Temkin isotherm models are furnished in Table 3. However, the Langmuir model is the perfect fit in this study as reported earlier for the removal of $\mathrm{Ni}(\mathrm{II})$ and other heavy metals [9, 35-36].

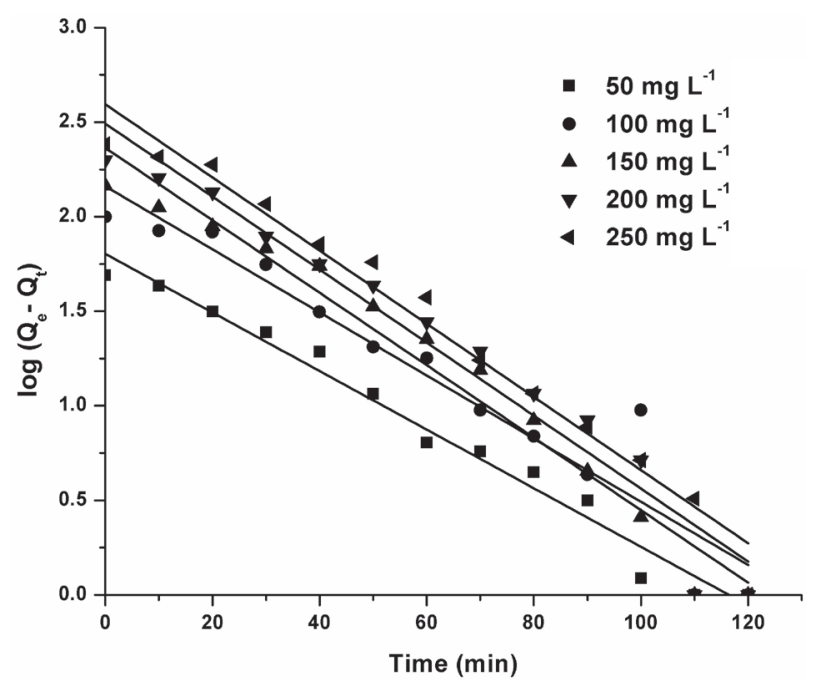

Fig. 7. Lagergren's pseudo first order kinetic plots for biosorption of Ni (II) by Citrus limetta peel biochar.

\section{Kinetic Model}

The kinetics of divalent nickel ion adsorption on to the Citrus limetta peel biochar were determined by pseudo first-order and pseudo second-order equations using data obtained from optimized conditions. In the case of the pseudo first-order model, the correlation coefficient $\left(\mathrm{R}^{2}\right)$ was found to be 0.98 , indicating that the model perfectly fits the kinetic data for the adsorption system in the present study (Fig. 7). But for the pseudo second-order $\left(\mathrm{R}^{2}=0.787\right)$, kinetic data was incapable of explaining the sorption kinetics suitably. In addition, from Table 3 it can be concluded that the adsorption of $\mathrm{Ni}$ (II) on the surface of Citrus limetta peel biochar effectively followed the pseudo first-order kinetics as demonstrated earlier with $\mathrm{Cr}(\mathrm{VI})$ on to Citrus limetta peel biochar [9] and Ni(II) on to Thespesia populnea bark [37]. The adsorption reaction proceeds through the following three steps: (1) transmitting adsorbate from bulk solution to adsorbent surface, (2) moving the adsorbate into pores, and (3) the interaction of adsorbate with accessible sites on the inner surface of pores [38].

\section{Conclusion}

The present study evaluates the use of Citrus limetta peel biochar for the removal of $\mathrm{Ni}$ (II) ions from aqueous solution. The removal of $\mathrm{Ni}$ (II) ions was found to be reliant on different parameters such as adsorbent dose, contact time, $\mathrm{pH}$, and initial concentration. The study validates that the removal was more than $99.8 \%$ of 
$\mathrm{Ni}(\mathrm{II})$ when the concentration was $100 \mathrm{ppm}$ at $\mathrm{pH} 7$ over 120 min. The Ni(II) adsorption on Citrus limetta peel biochar followed the first-order kinetics. The adsorption data befittingly match the Langmuir isotherm. Furthermore, this was sufficiently proved from morphological structure analyses like SEM and FT-IR, which showed that the surface of the biochar had a higher number of pores or sites available for adsorption. The Ni(II) ions were bound to the active sites of the biosorbent, Citrus limetta peel biochar, through either electrostatic attraction or a complex forming mechanism. Higher adsorption capacity indicates that Citrus limetta peel biochar can be used efficiently to remove $\mathrm{Ni}$ (II) ions from industrial effluents by using the cost-effective adsorption technique.

\section{Acknowlegements}

The first author is grateful to the Departments of Environmental Science of the PSG College of Arts and Science, Coimbatore, and of the Tamil Nadu Agricultural University, Coimbatore, India, and the Department of Chemistry, National College, Tiruchirapalli, India for providing facilities and extending cordial gestures during the course of her doctoral programme throughout this study.

\section{References}

1. KINHIKAR V.R. Removal of nickel (II) from aqueous solutions by adsorption with granular activated carbon (GAC). Res. J. Chem. Sci., 2 (6), 6, 2012.

2. HAE WON KIM, JEONG-MUK LIM, SAE-GANG OH, SERALATHAN KAMALA-KANNAN, MIN CHO, BYUNG-TAEK OH. Nickel ion adsorption behavior of Ceriporia lacerata isolated from mine tailings in Korea. J. Soil Groundw. Environ., 20 (2), 22, 2015.

3. OLUGBENGA SOLOMON BELLO, KAYODE ADESINA ADEGOKE, OLYINKA UTHMAN BELLO, IBRAHIM OPEYEMI LATEEF. Sequestering nickel (II) ions from aqueous solutions using various adsorbents: A Review. Pak. J. Anal. Environ. Chem., 15 (1), 1, 2014.

4. RAHIM A.A., GARBAA Z.N. Efficient adsorption of 4-Chloroguiacol from aqueous solution using optimal activated carbon: Equilibrium isotherms and kinetics modelling. J. Assoc. Arab Univ. Basic and Appl. Sci., 21, 17, 2016.

5. VIDHYADEVI T., RAVIKUMAR L., SRINIVASAN S. Adsorption kinetic, equilibrium and thermodynamic investigations of $\mathrm{Zn}$ (II) and $\mathrm{Ni}$ (II) ions removal by poly (azomethinethioamide) resin with pendentchlorobenzylidine ring. Pol. J. Chem. Technol., 17 (3), 104, 2015. DOI: 10.1515/pjct-2015-0057.

6. NASTAJ J., PRZEWLOCKA A., RAJKOWSKA-MYSLIWIEC M. Biosorption of Ni(II), Pb(II) and $\mathrm{Zn}(\mathrm{II})$ on calcium alginate beads: equilibrium, kinetic and mechanism studies. Pol. J. Chem. Technol., 18 (3), 81, 2016. DOI: 10.1515/pjct2016-0052.

7. MUTHUSELVI R., VASHANTHA R. Kinetic and isotherm studies on adsorption of nickel (II) ions by Brassera oleracea as a bioadsorbent. Intern. J. Sci. Res., 5 (4), 2319, 2016.
8. SHENBAGAVALLI S., MAHIMAIRAJA S. Production and characterization of biochar from different biological wastes. Intern. J. Plant Agricult. Sci., 2 (1), 2231, 2012.

9. VIDHYA L., DHANDAPANI M., SHANTHI K., MAHIMAIRAJA S. Activated Citrus limetta peel for the removal of hexavalent chromium from aqueous solution. Global J. Environ. Sci. Res., 3 (2), 51, 2016.

10. SHAH M.A., TOKEER AHMAD. Principles of Nanoscience and Nanotechnology, Narosa Publishing House, New Delhi, 2013.

11. VARGAS C., BRANDAO P.F.B., AGREDA J., CASTILLO E. Cr (VI) removal by compost. BioResources, 7 (3), 2711, 2012.

12. KUCIC D., MARKIC M., BRISKI F. Ammonium adsorption on natural zeolite (clinoptilolite): adsorption isotherms and kinetics modelling. The Holistic Appro. Environ., 2 (4), 145, 2012.

13. RAZIYEH ZANDI PAK, SOHEIL SOBHAN ARDAKANI. Evaluation of kinetic and equilibrium parameters of $\mathrm{NiFe}_{2} \mathrm{O}_{4}$ nanoparticles on adsorption of reactive orange dye from water. Iranian J. Toxicol., 10 (2), 51, 2016.

14. PRAGATHISWARAN C., SIBI S., SIVANESAN P. Comparison studies of various adsorption isotherms for Aloe vera adsorbent. Intern. J. Res. Pharm. Chem., 3 (4), 886,2013

15. LANGMUIR I. The adsorption of gases on plane surfaces of glass, mica and platinum. J. Am. Chem. Soc., 40 (9), 1361, 1918.

16. MOAAZ K. SELIEMA, SRIDHAR KOMARNENI. Equilibrium and kinetic studies for adsorption of iron from aqueous solution by synthetic Na-A zeolites: Statistical modeling and optimization. Microporous and Mesoporous Materials, 228, 266, 2016.

17. FREUNDLICH H. Über die Adsorption in Lösungen Engelmann, 98, 1906.

18. YASIM N.S.E.M., ISMAIL Z.S., ZAKI S.M., AZIS M.F.A. Adsorption of $\mathrm{Cu}, \mathrm{As}, \mathrm{Pb}$ and $\mathrm{Zn}$ by banana trunk. Malaysian J Analy. Sci., 20 (1), 187, 2016.

19. TEMPKIN M.I, PYZHEV V. Kinetics of ammonia synthesis on promoted iron catalyst. Acta Physica-Chimica USSR 12, 327, 1940.

20. LAGERGREN S. 1898. Zur theorie der Sogenannten adsorption Gelöster Stoffe. Kungliga Svenska Vetenskapsakademiens-Handlingar, 24, 1, 1898.

21. HO Y.S., McKAY G. A kinetic study of dye sorption by biosorbent waste product-pith. Resources, Conservation and Recycling, 25, 171, 1999.

22. ASHA GUPTA, REENA YADAV, PARMILA DEVI. Removal of hexavalent chromium using activated coconut shell and activated coconut coir as low cost adsorbent. The IIOAB Journal, 2 (3), 8, 2011.

23. ABDELHAFEZ A.A., LI J. Removal of $\mathrm{Pb}$ (II) from aqueous solution by using biochars derived from sugar cane bagasse and orange peel. J. Taiwan Inst. Chem. Eng., 61, 367, 2016.

24. TALOKAR A.Y. Studies on removal of chromium from waste water by adsorption using low cost agricultural biomass as adsorbents. Intern. J. Adv. Biotechnol. Res., 2, (4), 452, 2011; http:// www. bipublication. com.

25. VINODHINI V., ANBARASU V., NIRANJAN DAS. Screening of natural waste products for the removal of $\mathrm{Cr}$ (VI) ions from industrial effluents. Indian J. Nat. Prod. Resour., 1 (2), 174, 2010.

26. SHANMUGAPRIYA A., HEMALATHA M., SCHOLASTICA B., AUGUSTINE ARUL PRASAD. Adsorption studies of lead (II) and nickel (II) ions on 
chitosan-G-polyacrylonitrile. Der Pharma Chemica, 5 (3), 141, 2013; http:// derpharmachemica. com/archive.html.

27. MAHER E SALEH, AMAL H MOHAMOUD, MOHAMED RASHAD. Biochar usage as a cost-effective bio-sorbent for removing NH4-N from wastewater. International Conference on Global Climate Change, Biodiversity and Sustainability: Challenges and Opportunities, April 15-18, 2013, Alexandria, Egypt.

28. HOSSAIN M.A., HAO NGO H., GUO W.S., NGUYEN T.V. Removal of copper from water by adsorption onto banana peel as bioadsorbent. Intern. J. Geomate, 2 (4), 227, 2012.

29. VIDHYA L., DHANDAPANI M., SHANTHI P., MAHIMAIRAJA S. Mesolite, a natural adsorbent, for the removal of hexavalent chromium (VI) From Aqueous Solution. Chem. Sci. Rev. Lett., 5 (18), 151, 2016.

30. BENNETT R.M., CORDERO P.R.F., BAUTISTA G.S., DEDELES G.R. Reduction of hexavalent chromium using bacteria and fungi isolated from contaminated soil and water samples. Chem. Ecol., 29 (4), 320, 2013.

31. DEVECI H., KAR Y. Adsorption of hexavalent chromium from aqueous solutions by bio-chars obtained during biomass pyrolysis. J. Indust. Eng. Chem., 19 (1), 190, 2013.

32. KATSOU E., MALAMIS S., HARALAMBOUS K.J., LOIZIDOU $M$. Use of ultrafiltration membranes and aluminosilicate minerals for nickel removal from industrial wastewater. J. Memb. Sci., 360 (1-2), 234, 2010.
33. MAO J., WON S.W., VIJAYARAGHAVAN K., YUN Y.S. Immobilized citric acid-treated bacterial biosorbents for the removal of cationic pollutants. Chem. Eng. J., 162 (2), 662, 2010.

34. ARIVOLI S., MARIMUTHU V., RAVICHANDRAN T., HEMA M. Kinetics, equilibrium and mechanistic studies of nickel adsorption on a low cost activated calcite powder. Indian J. Sci. Res. Techno., 1 (1), 41, 2012; http:// www. indjsrt.com.

35. MARIA VISA, NICOLETA POPA. Adsorption of heavy metals cations onto zeolite material from aqueous solution. J. Memb. Sci. Technol., 5 (1), 133, 2015.

36. KHALIL, T.E., EL-DISSOUKY A., RIZK, S. Equilibrium and kinetic studies on $\mathrm{Pb}^{2+}, \mathrm{Cd}^{2+}, \mathrm{Cu}^{2+}$ and $\mathrm{Ni}^{2+}$ adsorption from aqueous solution by resin 2, 2'- (ethylenedithio) diethanol immobilized amberlite XAD-16 (EDTDEAXAD-16) with chlorosulphonic acid. J. Molec. Liqu., 219, 533, 2016.

37. PRABAKARAN R., ARIVOLI S. Adsorption kinetics, equilibrium and thermodynamic studies of nickel adsorption onto Thespesia populnea bark as biosorbent from aqueous solutions. European J. Appl. Eng. Sci. Res., 1 (4), 134, 2012.

38. MERVETTE EI BATOUTI, ABDEL-MONEIM AHMED M. Kinetics of nickel (II) onto activated carbon prepared from natural adsorbent, rice husk. Intern. J. Technol. Enhance. Emer. Eng. Res., 2 (5), 145, 2014. 